\title{
Split Consciousness and the Poetics of Inauthenticity: Reading Anatole Broyard's Kafka Was the Rage
}

\author{
Amr Elsherif \\ "and that was what I wanted, to be revised. I saw myself as a first draft." \\ (Broyard 1997: 48)
}

\begin{abstract}
Anatole Broyard's life story makes for a good suspense film or mystery novel: a black man who passes for white, severs all relations with his family, marries in order to avoid military service but is drafted anyway, leaves his first darkskinned wife and child after finishing his army service, lives a bohemian life with artists in Greenwich Village, becomes a successful writer, critic and editor of The New York Times Book Review, marries a blonde of Norwegian-American ancestry, becomes, as described by the literary scholar and Harvard professor Henry Louis Gates, "one of literary America's foremost gatekeepers" and an "arbiter of American writing", and refuses to disclose his secret to his children till near his death (Gates 180,199). It was only two months before his death that the secret was revealed and his children came to find out through their mother that their father was black (Bliss Broyard 3). Broyard had to pass in order to avoid the restrictions placed on African-Americans by the Jim Crow laws and the One-drop rule in the forties.
\end{abstract}

\section{Broyard's Vision of Art, Life and Politics}

In the fifties, Broyard was asked by The Atlantic Monthly Press to write an autobiographical novel and was offered a handsome amount of money for it. Everybody waited eagerly for the novel that was never written. It is remarkable that the kind of autobiography Broyard chose to write, near the end of his life, was a memoir not a complete autobiography. He chose to frame what would be told and cut out what would be left unsaid. Kafka Was the Rage is a "Greenwich Village Memoir;" it starts at a certain point before which earlier history is excluded or selectively included. The memoir is divided into two parts, "Sheri" and "After Sheri"; the first of which is centered on the title character while each chapter of the second is dedicated to one or more of Broyard's acquaintances. Due to the fact that he provides no intimate and uninhibited description of his

\footnotetext{
*Faculty of Arts, Damanhour University.
} 
own consciousness, any account of it has to be gleaned from the noetic acts correlative of the noemata of the intended phenomena; i.e. from how he saw people and events (Brainard 135). The main act of consciousness in writing a memoir -noesis- is remembering. Nevertheless, as Broyard's style clearly shows, he was not only remembering people and events but was also writing in a highly figurative style. He was also forming and constructing - another noesis. Due to eliminating any reference to his colored background in the memoir, it becomes clear that Broyard's consciousness was not only remembering but also suppressing. Although this may go beyond the limits of pure description, it may be safely presumed, as will be discussed later, that he was constructing to cover up what was suppressed. The exquisite style in which the memoir is written creates a layer of figurative language which envelops what is remembered - the noema - in an auratic veil that hypnotizes the reader and sets the narrated objects of remembrance apart from the consciousness which perceived them in the first place. In other words, the noetic acts of forming and stylizing are overtaking those of perceiving and remembering. Unlike Marcel Proust's À la Recherche du Temps Perdu, Kafka Was the Rage does not seek to reveal the identity of the narrating consciousness through the remembered objects, but rather concentrates on the people and objects for their own sake. This does not mean, though, that the style and figuration are there as a mere veil; they stand in their own right for the beauty they create. Due to the thick layer of figurative language, the memoir stands on its own as an autonomous literary work of art separate from the actual lived experience it is supposed to relate. Broyard was writing an anti-subjective kind of autobiography, a history of people and objects not of the self. Hence, to glean how the remembering consciousness saw the noema and understand the corresponding noetic acts is to read the text against the grain.

Broyard depicts an image of Greenwich Village in the forties as a harmonious mixture of life and art; a place where people came to "be with art, to live near it" (Broyard 1997: 141). People's lives were suffused with art; high cheek bones were prized above anything else a girl could have due to the influence of Cubism. Broyard says: "I slept with modern painting" (57). The memoir starts with a description of Sheri Donatti - a pseudonym for Sheri Martinelli (1918-1996), the painter and poet with whom Broyard lived.

Sheri was her own avant-garde. She had erased and redrawn herself, redesigned the way she walked, talked, moved, even the way she thought and felt.

She was a painter and she looked more like a work of art than a pretty woman. She had a high, domelike forehead, the long silky brown hair of women in portraits.... Her gestures and motions were a slow dance, a 
parody of classical poses. They were very deliberate, performed at half speed, as if she had to remember each time, to remind herself, how human beings behaved.... She was a preview of things to come, an invention that was not quite perfected, but that would turn out to be important, a forerunner or a harbinger, like the shattering of the object in Cubism or atonality in music. When I came to know her better, I thought of her as a new disease. (3-4) [Italics mine $]^{1}$

Sheri is not only an artist; she is herself a work of art. In the Greenwich Village utopia, art was no longer exiled; Plato's age-old banishment of art seems to have come to end and the latter has finally become part of life as Broyard suggests.

Nevertheless, an investigation of how the phenomenon of art appeared to Broyard's consciousness would not render the image so seamless or show art and life to be such a harmonious mixture. Broyard did not regard Sheri as a normal person like most people but as a different and distinguished individual; she is separate from both her own past and life around her. She erased the person she was and recreated herself in everything she did as a living work of art. She became as separate from life and as artistically formed and meticulously calculated as an autonomous high modernist work of art. It is noteworthy that the art techniques Broyard mentions, the shattering of the object in Cubism and atonality in music, were the peaks of modernism in the forties, the most important characteristic of which is autonomy in both senses of separation from life and revolt against the past. It is also remarkable that art is the constant figure of speech used to refer to Sheri all through the memoir -one would be tempted to say metaphor but this is largely inaccurate as will be clear later- and that Broyard conceived of art as essentially autonomous. Art may influence life; distinguished individuals may bear some resemblance to a work of art but this does not cancel out the distinction between them. Both Sheri and art appeared to Broyard's consciousness separate from life and the past. She appeared to him like a closed sphere. He yearned to achieve intimacy with her but never managed to:

She was an abstract painter and I couldn't follow her there. She left me outside, like a dog that you tie to a parking meter when you go into a store. I had no talent for abstraction, didn't see the need for it, or the beauty of it. Like liberal politics, it eliminated so many things I liked.

Yet, if I could understand her paintings, I thought, our sex would be better. We would exist in the same picture plane, pose for each other's portraits, mingle our forms and colors, make compositions. We would be like two 
people walking through a gallery or a museum, exclaiming over the same things.

I began to read about abstract painting.... I had come to think that modern art was an initiation into that life, like the hazing before you get into a fraternity. (12)

Not only is abstract painting autonomous but, through its abstraction, it also takes away from art all the details that relate it to life. It exists in an isolated sphere which must be passed through as a transitional period of hazing before one can join the distinguished world of artists. In its abstractness, it appeared to Broyard to resemble liberal politics which, in ignoring many of the particularities and even prejudices of culture, would also be separate from life. Broyard may not have understood abstract art or even liked it yet he saw it as serious art, something that must be learnt in order to belong to the circle of artists and intellectuals living in Greenwich Village - the center of hip life in the forties.

Broyard reflects on his life in the Village through comparing it to literature. He opened a secondhand bookstore in the Village:

It was the talkers who gave me the most trouble. Like the people who sold me books, the talkers wanted to sell me their lives, their fictions about themselves, their philosophies....

While I pretended to listen, I asked myself which were more real theirs, or the stories on the shelves. "The familiar man makes the hero artificial," Wallace Stevens said.... As they talked on, I thought of all the junk I had carried out of the shop.... These people were bringing it all back. (33)

The distinction between art and life, as it appeared to Broyard's consciousness, is not only a matter of degree and concentration of emotions. While both real people and books may tell stories, those told by people do not seem real enough; they seem artificial. To tell a good story, realistic or otherwise, technique and expertise are required. Art, as Broyard perceived it, depends on technicality - a cornerstone of modernism. Talking about Meyar Schapiro's art class, Broyard expounds his understanding of modern art:

I remember Schapiro telling us that before Cézanne, there had always been a place in a landscape painting where the viewer could walk into the picture. There was an entrance; you could go there, like walking into a park. But this was not true of Cézanne's landscapes, which were cut off 
absolutely, abstracted from their context. You could not walk into them you could enter them only through art, by leaping. (59)

Before modernist painting, a landscape and life were perceived as a continuum; there was usually a path which the viewer could trace with his eyes and which walked him into the painting; art was part of life. With modernism, they became separate. Art proper appeared to Broyard to be separate from life. Whatever resemblances it may bear to life have to be redrawn and recreated for art to become art. Whether he liked abstract painting or not, Broyard wanted to understand it in order to belong. "Modern painting was one more exclusion, one more mystery from which I was shut out.... But when it came to modern art, I was afraid that maybe the others were right, that I would never be hip or sophisticated, would never belong" (57). Modern art was seen as a pass to the chic world of connoisseurs. It is the center which marks the circumference and sets the distinguished inside apart from the ordinary outside. In order for Broyard to be separate from ordinary society and his humble background, to gain distinction, art appeared absolutely necessary. "The life we had depended on modern art. Without that, all we had was a dirty apartment" (57). Art is added to life to endow them with a sense of distinction. Art and life were not unified in the sense they were before modernity, the rationalization of art, the appearance of aesthetics and the bifurcation of reason into the three separate domains of truth, morality and beauty. Art remains a separate sphere admissible only to the distinguished few who can understand it and this is why it imparts a sense of distinction. In order to belong to the company of Sheri -who separated herself from life and recreated herself like a work of art- the hip artists and sophisticated critics in Greenwich Village, Broyard had to erase his past, go through a transitional phase and recreate or redraw himself.

Unlike the autonomous art of high modernism, Jazz appeared to Broyard in a totally different way. Whereas he did not like abstract art but found it necessary to understand, he liked Jazz yet did not perceive it as a real form of art. Apart from the split between his feelings and intellect or aesthetic judgment and the irony -both of which will be discussed later- Broyard, comparing Jazz to modernist art, saw that the former lacked the essence of art: "Was it like Les Demoiselles d'Avignon, a fracturing of music, like the splitting of the atom?... It seemed to me that Jazz was just folk art. It might be terrific folk art, but it was still only local and temporary" (70). For Broyard, Jazz smacked of life, of folks; it was not separate or autonomous and did not have universal value. He found an analogy for it in a story told by Gregory Bateson who lived with a primitive tribe in New Guinea for some time and used to hear a man beating the drums every day at dawn: 
Bateson learned that this man had suffered a grievance that he could not get settled. The tribe had rejected his plea for redress and so he got up every morning and rehearsed his complaint to the village. He tried to wake them, to disturb their rest, invade their dreams. Thinking about Jazz, I remembered this man and I thought that Jazz musicians were something like that. (71)

Jazz bore the grievances of African-Americans. It was a form of complaint, an expression of the suffering and injustice sustained in life. It was not separate enough from life and "relied too much on improvisation to be a full-fledged art form" (70). In addition to autonomy, Broyard saw real art as highly investing in its technicality which, unlike improvisation, is the element that recreates all the elements that go into the making of art into something new and self-sufficient.

Communist politics, like Sheri, abstract painting and liberal politics seemed separate from life. "When I was at Brooklyn College, everyone urged me to join the Communist Party, but I refused because I thought it was an uninteresting quarrel with the real. Modern art, though, was a quarrel that appealed to me more" (12). Broyard saw that communism, like liberalism, distanced people from "the ordinary" to which he, seeing himself as an "insider," belonged. Yet, Broyard did not reject abstract art as he did with liberal and communist politics. While all of them seemed separate from life, the latter two appeared to be alienating. Modern art, on the other hand, was seen as a pass to Sheri and the elite world of artists. ${ }^{2}$ Sheri herself was seen as a successful project of recreating the self, much like a work of art that transfigures its components into a new ontological mode.

Broyard describes The New School, which was full of German professors who fled from Hitler, as "the "University in exile." It was also separate from American life "as if it were a concentration camp" (15). Like all the previous objects of remembrance, the university too was separate from the context in which it existed. Nevertheless, Broyard -who saw himself as an "insider," as part of the context of the ordinary American life to which the intellectuals he knew did not belong- ironically perceived himself and the people in Greenwich Village as also separate from the past and isolated from the ordinary. Like Sheri, they had to recreate themselves and fashion a new life distanced from the ordinary.

When I left Brooklyn to live in the village, I felt as if I had acquired a new set of relatives, like a surprising number of uncles I had never seen before... who had shunned family and been shunned in turn .... There was a flaw in their past, some kind of unhealthiness, even a hint of insanity....

They were all the family that I had now, all the family that I wanted. With them, I could trade in my embarrassingly ordinary history for a 
choice of fictions. I could lead a hypothetical life, unencumbered by memory, loyalties, or resentments. The first impulse of adolescence is to wish to be an orphan or an amnesiac. Nobody in the village had a family. We were all sprung from our own brows, spontaneously generated the way flies were once thought to have originated. (28-9)

The movement from Brooklyn to Greenwich Village, like growth from childhood to adolescence, did not appear to Broyard as a process of development but as a rupture. Everyone in the Village appeared separate from any family or history. He recreated a new life in which family was replaced by books.

In all these phenomena, the noematic pole of Broyard's intentional acts of consciousness was the separateness of these phenomena from their histories and contexts. On the noetic side, separate phenomena that appeared alienating like liberal and communist politics were regarded negatively and rejected. Those that appeared to involve reinvention or transfiguration like Sheri, The New School, modern art and Greenwich Village itself appeared positive. The phenomena that did not appear separate enough, those that smacked of life like jazz, were relegated to a lower position.

The movement to Greenwich Village and the replacement of family by books were acts of recreating the self. "We didn't simply read books; we became them. We took them into ourselves and made them into our histories" (30). Moving to live with Sheri seemed also like a process of recreating oneself. "Living with Sheri was a process of continual adjustment. It was like living in a foreign city: You learn the language, the currency, the style of the people" (40). Having to go through such a process of erasing and redrawing oneself is ironic for someone who saw himself as an "insider" and regarded it as a distinction.

While Broyard wanted to belong to the distinguished sphere of artists, authors, critics and intellectuals, he saw himself separate from them by his intimate understanding of the real. Unlike them, he conceived of himself as someone who never lost touch with life and actuality. "I wanted to be an intellectual, too, to see life from a great height, yet I didn't want to give up my sense of connection, my intimacy with things. When I read a book, I always kept one eye on the world, like someone watching the clock" (111). Broyard saw himself distinguished by his immediacy to life - the quality that others lost due to their separateness.

\section{Broyard's Split Consciousness}

One of the most revealing chapters in the memoir relates the story of Saul Silverman, a young Jewish intellectual who came to know that he was terminally ill and was going to die shortly. Silverman was so rational and contemplative 
that when he referred "in a convoluted, Jamesian way to a female companion," she appeared to Broyard more like a "theory of femininity, a sketch for a character" (96). Silverman was one of those thinkers who were separated from life by abstractions, by their intellect and by their consciousness of being different. "He was looking around at the park as if he was taking notes, summing it up, trying to arrive at a definition of the ideal park. He was comparing this one to other parks he had only read about" (100). Silverman, inter alia, was not capable of immediate contact with life because he was constantly thinking in the abstract. He was even alienated from his body; he regarded it as a vehicle or a machine, a mere receptacle for his consciousness or soul which is separate from it; he saw it as an other. "I've hardly used this body. It's the shoddy manufacture of the times - I'm practically new and obsolete already" (105). ${ }^{3}$ His behavior and reactions were not spontaneous but were determined by his sense of distinction and difference. When Broyard came to know that Silverman had Leukemia, he was so angry and wanted to vent out his feelings but the latter stopped him. "We're not ordinary people, you and I - I don't see why we should feel obliged to become ordinary now" (103-104). Unlike Silverman, Broyard did not see himself so alienated -even from himself- or lacking immediacy.

He had invited me to stand outside the event with him, as a fellow critic - but I couldn't do it. I wasn't that intellectual. His situation brought out all the homeliness in me, the sloppiness. My feelings had no style. To Saul, my sympathy would have seemed almost bestial, the disorderly impulse of a more primitive civilization. He has always been lofty and distant. (107)

Unlike Silverman and other intellectuals, including Delmore Schwartz and Clement Greenberg, who lost touch with actuality because they were so "blinded by reading" and abstractions, Broyard saw himself not as an anti-intellectual but as someone who was in touch with the world and intimate with things, someone who did not lose immediacy; he did not lose touch with actuality, with people and, most importantly, with himself and his feelings. Broyard was the one who lived in the thick of American life, took his intellectual friends out, and introduced them to Spanish Harlem, night life, Latin dance and dancers.

Nevertheless, when Broyard's critical writings are read alongside his memoir, they do not confirm the same immediacy and intimacy he claims. In his 1950 article "Portrait of the Inauthentic Negro," Broyard extended Jean-Paul Sartre's analysis of the influence exercised by discriminating society on the psychology of the Jew to offer his description of the character of what he calls the "inauthentic negro" - the one who accepts the other's view of himself, whose self-understanding is mediated by the other. The inauthentic Jew or African- 
American is forced to remodel himself into certain character profiles which Broyard, following Sartre, calls "avenues of flight" that do not have "any necessary relation to his true self" (Broyard 1950: 57). Broyard describes the inauthentic character as follows:

Worst of all, the inauthentic Negro is not only estranged from whiteshe is also estranged from his own group and from himself. Since his companions are a mirror in which he sees himself as ugly, he must reject them; and since his own self is mainly a tension between an accusation and a denial, he can hardly find it, much less live in it. In extreme cases, he may be said to live wholly by conditioning from outside... In place of useful action, he has worked up an act. $(63)^{4}$

This description, which applies to Broyard himself, shows that his identity is conditioned by the discriminating society. Being forced to deny his identity in order to fit into society, Broyard's consciousness lost its authentic character and came to adopt an inauthentic guise. His self-consciousness is mediated by what he is not, by the other, by the outside. Because of this mediation, the outside constituted the inside and Broyard's identity consisted in a fissure; he saw himself as an other. He developed a second nature, an attitude of constant watchfulness which continuously held his true self in check and denied it. His identity, actions and reactions were mediated by what he reacted against. Broyard's relation to people, things and, most importantly, his own self is no less mediated than Saul Silverman's and the other intellectuals' from whom he sought to distinguish himself. If Silverman and the other intellectuals did not have immediate understanding of the world because their visions were mediated by their abstract conceptual intellects, Broyard's relation to the world was mediated by his consciousness of himself as an other, by his inauthenticity or self-denial. Broyard also is a man without immediacy. His inauthentic selfdivided consciousness determined the nature of his relation to himself and to other people and manifested itself in his poetic style.

While complete self-immediacy is an impossible ideal, with Broyard this is taken to the extreme. There is a gap separating two levels of consciousness. He regarded himself as one would regard someone else he envies - or perhaps pities. "I was like an immigrant who goes from a poor country to a rich one and can't quite believe in his new prosperity. I distrusted my happiness" (Broyard 1997: 46). He flaunted one part of himself and suppressed another which he had to keep in check all the time. During his years at The New School, he wanted to be psychoanalyzed. Talking to Dr Ernst Schachtel, he said: "As far as I can see, I said, I have no reason to be disappointed. Yet, something doesn't feel right. I don't 
feel that my happiness is mine. It's like I'm happy outside of myself' (50). Broyard saw his happiness as belonging to the image he projected not to the consciousness lurking behind this image. He was a man who saw himself living and acting and was tormented by this separation from himself.

What I brought to Dr Schachtel was not a condition or a situation but a poetics. I wanted to discuss my life with him not as a patient talking to an analyst but as if we were two literary critics discussing a novel. Of course, that's what all patients want, but the irony was that with me it might have worked. It might have been the shortest, or the only, way through my defenses, because I had a literature rather than a personality, a set of fictions about myself (52).

Ironically, he wanted to discuss himself with Dr Schachtel in the same manner Saul Silverman suggested: as two critics separate from what they discuss. Broyard saw himself as a fictional character; he created an image separate from himself. Like Sheri, Broyard erased and redrew himself as a work of art. He saw himself as a rough draft that needs to be revised (48). Yet, he was also the critic doing the revision. Only that erasure was not complete; he remained self-divided. While all people have images, ideas and understandings of themselves and can never achieve full immediacy to themselves or complete self-consciousness, Broyard's consciousness itself was split into a perceiving and a perceived consciousness or image. It was normal for such a wretched consciousness tormented by its separation from itself to wish for another state in which the split existence would come to end. "I want to be transfigured, I said" (51). He wanted the work of art which he was creating -his invented identity- to be consummated and all the relevance to history and life to be severed for the new ontological status to be achieved.

Like Silverman who felt that his body is a mere vehicle and Delmore Schwartz who described his body as "the heavy bear who goes with me" -the intellectuals from whom Broyard felt different- he was also alienated from his body (Delmore Schwarz quoted in Broyard 131). He felt the fissure between his body and soul and was aware of how it prevented him from achieving intimacy with many girls he knew:

Their souls lay beside us in the bed, watching, sorrowing. Perhaps I needed their souls -there is no other explanation for their inconvenient presencebut I didn't know what to do with them, any more than I knew what to do with my own. (146) 
Speaking of his illness and of the general and impersonal medical procedures used by his doctor to characterize his disease in Intoxicated by my Illness, he wrote: "Since technology deprives me of the intimacy of my illness, makes it not mine but something that belongs to science, I wish my doctor could somehow personalize it for me. It would be more satisfying to me, it would allow me to feel that I owned my illness" (Broyard 1993: 47). Broyard lacked immediacy first and foremost with himself. In this alienated state, his relation to life was as mediated as his intellectual friends' were; and perhaps more so.

As a manifestation of his lack of immediacy, Broyard could not be spontaneous with other people. His consciousness of separation from himself mediated his perception of all phenomena. He had to watch himself living, acting and reacting. Therefore, he was not in immediate contact with people, things and events. Like Silverman, he could not be spontaneous; not even with his own family. Talking about their conversations, Shirley Broyard, his dark-skinned sister, remembers that spontaneity was avoided:

"They always had to be focused on something, like a movie, because you couldn't afford to be very intimate. There had to be something that would get in the way of the intimacy." And when she phoned him during his illness it was the same way. "He never gave that up," she says, sounding more wistful than reproachful "He never learned how to be comfortable with me." (Gates 213)

Daphne Merkin, one of his close friends, spoke about a "tendency to want to establish a sort of safety through bourgeoisness" (Gates 195). Michael Miller, his psychiatrist and friend for thirty years, confirms that their "unusual intimacy was circumscribed by a subject that they never discussed" (Gates 195). His wife said that he put limits even to her and that when she tried to cross them, he would "bring down this "gate" (Gates 193). In the memoir, Broyard takes responsibility for alienating others and ascribes it to his desire for transfiguration. He acknowledges the alienating effects of constantly watching himself and orchestrating the process of metamorphosis. Speaking of some girls with whom he had fleeting relations, he writes:

If I had known how to reassure these girls, or if I had remained with any of them long enough, they might have relaxed and become natural with me and I with them. But I was driven with restlessness. I was still looking for transfiguration, as I had said to Dr. Schachtel - it was transfiguration or nothing. (Broyard 1997: 146) 
Whether this could be viewed as denying room for trust as Mariana Oshana is inclined to see it or as protecting his identity and personal space, in both cases this is a psychological interpretation of the deeper ontological condition described here (Oshana 65).

Broyard confirms that he belonged to ordinary American life in a way that others did not and that he enjoyed a degree of immediacy denied to the other artists and intellectuals with whom he lived. In the "Prefatory Remarks" to the memoir, Broyard writes:

While some of my contemporaries made a great show of political commitment, it seems to me that their politicizing of experience abstracted them from the ordinary, from the texture of things. They saw only a Platonic idea of American life. To use one of their favorite words, they were alienated. I was not. In fact, one of my problems was that I was alienated from alienation, an insider among outsiders. The young intellectuals I knew had virtually read and criticized themselves out of any feeling of nationality. (Broyard 1997: viii)

Broyard was not attracted to political affiliations not because he belonged to the ordinary American life but because he wanted to belong to it, to be an insider. While these intellectuals wanted to change what they found unsatisfying about it, Broyard idealized it as it is and preferred to change himself to fit into it. Being forced to deny part of himself to fit in, he created the fissure which shaped his split inauthentic consciousness.

In his pursuit of belonging, Broyard did not want to belong to the "embarrassingly ordinary" (29). In an article he published in his Times column, he wrote:

My mother and father were too folksy for me, too colorful.... Eventually, I ran away to Greenwich Village, where no one had been born of a mother and father, where the people I met had sprung from their own brows, or from the pages of a bad novel.... Orphans of the avant-garde, we outdistanced our history and our humanity. (Broyard quoted in Gates 186)

Broyard wanted to distance himself from that part of his personality and belong to the elite company of art, artists and Sheri, to live in Greenwich Village and study at The New School. All these objects appeared to Broyard's consciousness separate from life. In order to belong to any of them, he had to go through a phase of change and recreate himself like a work of art. This is why phenomena which appeared to him separate from life and involving a process of metamorphosis or 
transfiguration were accorded a positive value. This is ironic, nevertheless, for someone who regarded himself as an insider and held it as a distinction. The split of Broyard's consciousness into perceiving and perceived layers led to his lack of immediacy with himself and with phenomena around him. With people, it led to what was felt as lack of intimacy; with other phenomena, it led to the ironic relativization of value remarkable throughout the memoir.

\section{Broyard's Figurative Imagination}

When Broyard read passages of his memoir to Ellen Schwamm, she described them as "stilted and distant" as if he was hiding something. Broyard admitted that he was hiding the fact that he was black (Schwamm qtd in Gates 202). Following Gates, Brett Ashley Kaplan argues that Broyard's denial of his identity stunted his talent and that "it was precisely his inability to address the question of his passing that prevented him from writing" (129). While this was true for most of his life, near the end it exercised a different effect. It determined the form of the memoir and the nature of his poetic style. In writing his memoir, Broyard's mind was consciously doing the Freudian dream work of suppressing and displacing what his waking consciousness would not accept and forming what it could see. If Broyard saw part of himself as a fictional character, he was finally materializing this fiction in an actual work of art. The result is a memoir that may be lacking in intimacy but is by no means lacking in style and makes up for what is missing in the former by the exuberance of the latter. The memoir is a modernist literary work of art marked for its style and unexpectedly autonomous from its author.

Gates notes that Broyard's life is full of ironies and that over the years he learned to use them. His style also displays a plethora of ironies, both verbal and existential. Seeing himself as an insider and rejecting the politics that separated him from life yet being forced to deny part of his personality and recreate himself to be accepted into this life -thereby unconsciously condemning society while consciously endorsing it- was only one of many ironies in Broyard's life. Irony is not a mere strategy that he resorted to whenever he needed. If the abundance of ironies is not fortuitous, it needs to be grounded in his consciousness. In order to be who he is, Broyard had to separate himself from what he was. For a man who erased his personal history and redrew himself as a work of art, the past is real yet denied. His present character - "literature" to use his word- which is the only reality he has now is, nevertheless, fictional, untrue. This existential mode creates an ironic condition in which reality is denied and unreality is confirmed. All the present positions, relations, friendships and career are based on the untrue white identity he created. Speaking of books as his new family members, Broyard writes: "They were more real than anything I had ever known, real as 
only imagined things can be, real as dreams that seem so unbearably actual because they are cleansed of all irrelevances" (Broyard 1997: 29). The verbal ironies and the ironic situations with which the memoir abounds are manifestations of this basic ontological condition.

Broyard was separated from objects of experience by his realization that they do not belong to him but to his fictional self. Due to his split consciousness, everything appeared to him to have a dual value. When things have different values, they cannot be seen to have an intrinsic value in themselves. Their value depends on how they appear and what they mean to the perceiving self-divided consciousness. Therefore, everything Sheri said could sound "both" true and false (5); life could appear less true than literature (33); going to the psychiatrist would develop new repressions rather than free Broyard of the old ones (49). Modern art is deemed necessary and important even if not liked (57), while Jazz may be liked but not aesthetically appreciated (70). Broyard confirms that ethnicity appeared normal and acceptable to all people yet he did not acknowledge his own (95). The neurotic would be regarded, from a psychoanalytic point of view, healthier than the normal person - an idea which he found flattering because he, like all students at The New School, regarded himself as neurotic (17). Yet, neurosis could be regarded as a healthy sign of protest only if society is oppressive or discriminatory. While in his memoir Broyard does not show any sign of condemning society as either, his passing is such a condemnation. Although he was alienated and oppressed, Broyard rejected liberal politics as alienating and communism -which was regarded by some as a sign of revolt- as an uninteresting quarrel with the real (viii, 12). As a result of his separation from phenomena and his lack of immediate experience of what things are, they became ironic for him. Broyard's inauthenticity -his selfdivided consciousness in which the perceiving fictional identity he created hides the original self and constantly keeps it in check- manifests itself in the existential and verbal ironies of the memoir.

Irony may be the most salient feature of an inauthentic consciousness ascribing different values to the same phenomena due to its self-division. Yet inauthenticity manifests itself in Broyard's poetics in other ways as well. The need to narrate life without revealing identity requires an aesthetic distance that can be gained only via a certain manipulation of figurative language. The striking feature of Broyard's style is not irony but his overwhelming use of similes. The style of the memoir shows an abundance of figurations that renders it more like a prose poem than an autobiographical piece of writing. Compared to any other figure of speech, similes are incomparably preponderant. Sometimes the figures seem unmotivated and tend to create similarities rather than discover or describe them. Everything in the memoir is like something else. While the figures are 
enjoyable for their novelty and the sense of high culture that informs them, this is not a reason to abandon them as mere ornamentation used for their decorative function.

The concern with art, literature and culture and the derivation of figures from this domain is the factor that unifies the memoir and prevents it from falling into a mere remembrance of a series of unrelated events. While many rhetoricians tend to regard metaphor as an elliptical simile and equate the two figures, from a nonreductive point of view they are not only stylistically different but stem from different visions and perform distinct processes. Metaphor stresses the belonging of the tenor -or the target domain- to the category of the vehicle - or the source domain; simile, on the other hand, stresses the likeness yet keeps them separate. "It is sometimes said that while a simile invites the addressee to make a comparison between two unlike things, a metaphor requires the addressee to conceive of one thing as actually being another (unlike) kind of thing" (Carston 357). ${ }^{5}$

Broyard's split consciousness, in addition of course to his training in the new critical tradition, did not allow him to see art as a direct reflection or even unmediated expression of life. His figures do not grow out of realizing similarities in life, then capture and express them in a metaphorical form. This determines the nature of his figures to be similes not metaphors. While metaphors do not necessarily stem from a unified vision as the organic growth of experience in the way romantic thinkers conceived of, they still express the unity of the source and target domains. Broyard's consciousness did not conceive of such unity in the first place. As has been illustrated, Broyard viewed art -the source domain- as essentially autonomous and separate from life - the target domain. Therefore, to derive almost all his figures, similes and analogies from the domain of art is to distance life from its narration. This is precisely what his similes do; they distance the reader from the remembered life and the hidden identity. Life is ordinary and art is a process of transfiguration that can elevate the individual above ordinariness (Broyard 1997: 51). Without art, all he had was just a dirty apartment. Speaking of the dishes in the kitchen sink and of how they were hardly ever used, Broyard says that they were "like a sculpture or a painting of dishes by Magritte" (81). Replacing family with books and authors, he writes: "When I left Brooklyn to live in the Village, I felt as if I had acquired a new set of relatives, like a surprising number of uncles I had never met before... These uncles were, of course, my favorite authors" (28). Art must elevate, transfigure and exalt life but it is not an organic part of it. The distance between the source domain from which the figures are derived and the target domain, which parallels Broyard's lack of immediacy with life, makes any figuration of the unity of art and life through metaphors hard to conceive. 
Broyard's consciousness understands the two domains as essentially different yet attempts to find analogies that would elevate life or transfigure it to a higher level.

Speaking of his attempt to come closer to Sheri through learning about art, he writes: "We would be like two people walking through a gallery or a museum" (12). The "like" of all his similes is not fortuitous. It creates the analogy while betraying and testifying to the distance. Similes create a layer of artistic figuration that draws the reader into the literary and artistic figurative level. Sometimes the distance is stressed even more when Broyard uses "as if" to create his figures like when he describes The New School "as if it were" a concentration camp (15), books "as if they were" relatives or uncles (28), and these uncles as having an aura of scandal "as if they had run away with someone's wife or daughter" (29). The word "as if" suggests some aspect of similarity while denying it at the same time creating, thereby, an ironic effect. The irony destroys any nearness that may be suggested by the similarity and keeps the literal and figurative levels apart. The common denominator of simile and verbal irony here is the distance between the two parts of the trope which is carried to the extreme of making the signifier refer to a signified sense standing opposed to it in the case of irony.

Similes and analogies drawn from the domain of art are consistently used to elevate life to the level of art in a way that renders people and events glow with a heroic artistic aura - stressing thereby the distance between the representation and what is represented. Dick Gilman, one of Broyard's acquaintances who was infatuated with literature and used to identify with the authors he liked while he read them, came to take Sheri away from Broyard. The latter realized that Gilman was in his D.H. Lawrence phase; Sheri became Frieda and Broyard became Ernest Weekley. With the idea of incongruity gaining importance in literary criticism at that time, Gilman described Broyard and Sheri as an incongruous couple (20). Nemecio Zarante, a painter who repeated Gilman's attempt, saw the problem as one of asymmetry. He looked "like a priest of the Inquisition"; his features were carved "as an El Greco portrait of a cardinal or pope"; Sheri was seen "as a quattrocento Madonna" and Broyard "felt like a man being persecuted." Broyard in his bookshop imagined himself "like Saint Jerome in his study" (23). Rather than foregrounding the remembered events, Broyard reconstructs them in symmetrical figurative narratives in which the domain where the similes come from determines the figures and characters which he, Sheri and the intruder assume. The figuratively constructed narratives cover up the narrated life.

The development of the relation between Broyard and Sheri is also depicted in figures derived from the domain of art. Referring to his sex life with Sheri in 
the beginning of their affair, Broyard sees himself as a "piston" and Sheri as "Paul Klee's Twittering Machine" (11). She was more developed and turned his monotony into something rich with variations. Later on, he uses one of his favorite images to refer to their relation. "When I connected myself to her, we were like the chance meeting, on an operating table, of a sewing machine and an umbrella" (61). It is remarkable that the tenor and the vehicle of Lautréamont's metaphor do not depict a coherent image and retain a gaping distance. With Sheri, Broyard always felt separate, lonely and solitary (63-65). Finally, due to their inability to achieve intimacy, they fell apart. Rather than discussing the reason why he could not be intimate with Sheri, their separation is represented in a figurative way as a dispute over an abstract painting of Broyard that she made - Anatole's Ontological Conspiracy - which he took away when he left. Sheri informed the police of a precious painting stolen and accused him. In the police station, the police detective forced him to choose between being prosecuted and leaving the painting which seemed to him meaningless. Broyard was finally forced to leave it. In this struggle between art and life, the latter won. Yet, the struggle itself is presented in artistic terms setting it apart from the life it covers. The separation between remembered life and its figurative narration or, rather, the figurative structuring of the narration of real life events, results from Broyard's attempt to conceal his identity while telling his story. While the highly ornamental style was characteristic of the high modernism of Greenwich Village writers, with Broyard it was an attempt to escape from personality and cover it up while representing it.

The whole memoir can be read as the chronicle of this struggle between life and art, between artists and intellectuals who were separate from life and Broyard who regarded himself as an insider who never lost touch with life but was, temporarily, flying in the autonomous realm of art. ${ }^{6}$ Broyard's selfconscious stylization of the memoir as a prose poem rather than an intimate narration of life, divided self-consciousness, self-denial, desire to recreate himself through entering the autonomous sphere of art and artists and, most importantly, living all his life under the guise of the character he created in the Village, nevertheless, contradict with his attempt to paint a portrait of his life there as a temporary flight, and of himself as an insider intimate with ordinary life and offer a different one.

Broyard's figures of speech tear themselves off from life and flaunt themselves in a way that makes them stand autonomous vis-à-vis the real life events they relate to. They create a figurative layer which makes the memoir harmonious through the source domain from which the similes are derived and, ironically, render the memoir an autonomous work of art in its own right. Broyard did not write the memoir as a remembrance of his past life or revelation 
of his identity but as his vision, or rather revision, of himself as he wanted to see it. He wrote the fiction of the transfigured self that he wanted Dr Schachtel to help him create, the self elevated through art to an exalted level of existence. ${ }^{7}$

Broyard revised himself from a draft into a polished work of art. Yet, the traces of the process of revision are still visible in the contradictions and ironies of the split consciousness. While on one level he was remembering, on another he was suppressing and constructing. While he saw himself as immediate, he was constantly watchful of himself and separate from it and others by this heightened degree of self-consciousness. For Broyard, "[t]o be acutely conscious ... [was definitely] a disease" (Dostoevsky 7). Not only did Broyard's dual consciousness make him lose immediacy with life, other people and himself but it also rendered the value of any object dependent on what it meant to the perceiving strata of consciousness. Consequently, objects lost any intrinsic value. Broyard's loss of immediacy not only relativized and ironized his vision of objects but also made any vision of unity with life impossible which, in turn, excluded a metaphorical vision based on the unity of self and life. The attempt to elevate life to an artistic level without intuiting any unity left him with no other means but similes which enveloped life in an artistic veil meant to cover the layer beneath it and enchant the readers with its own aura.

Broyard's flight into the realm of art was not as temporary as he may have thought or wanted the reader to believe. Like Sheri, Broyard was a work of art and remained so. Like all the intellectuals from whom he sought to distinguish himself, he was also separate from life. In the ironies of his memoir, those of his own personality can be read and in the contradictions of the latter, those of American society can be clearly seen.

\section{Endnotes}

${ }^{1}$ Broyard uses the word "avant-garde" throughout the memoir in the familiar sense to refer to a high modernist work of art or an artist interested in or whose works display an advanced state of modernist aesthetics. He does not use it in the more technical sense of attack on the autonomy of modernist art. It is also worthwhile to mention early on that throughout the memoir Sheri continues to be compared to works of art. It should also be mentioned that the words "like," "as" and "as if" will be italicized throughout the article.

${ }^{2}$ While the relation between modernist art and elitism is well known, a good succinct explanation can be found in José Ortega Y Gasset's The Dehumanization of Art. Modern art, on the other hand, will always have the masses against it. It is essentially unpopular; moreover, it is antipopular. It is not that the majority does not like the art of the young 
and the minority likes it, but the majority, the masses, do not understand it. When a man dislikes a work of art, but understands it, he feels superior to it; and there is no reason for indignation. But when his dislike is due to a failing to understand, he feels vaguely humiliated and this rankling sense of inferiority must be counterbalanced by indignant self-assertion. Through its mere presence, the art of the young compels the average citizen to realize that he is just this - the average citizen (5-6). Modernist art is elitist by nature. Most, if not all, of the artworks that Broyard mentions in the memoir are modernist.

${ }^{3}$ It is important here to refer to Derrida's commentary on Hegel's understanding of Jewish consciousness as separate from the body. In Glas, Derrida writes:

So he cannot enjoy (this). Since everything is obtained through the favor of a transcendent and separate God, what the Jew enjoys is under the seal of expropriation. What I enjoy does not belong to me. My life and my body are not mine.... Since the human body belongs to God, it had to be kept clean... but like a disguise..., like the livery of a servant. (50)

Broyard's unacknowledged sense of separation from his body is similar to that of Saul Silverman and the other intellectuals in whom he realized the same phenomenon yet sought to set himself apart.

${ }^{4}$ In Blacks and Jews in Literary Conversation, Emily Miller Budick criticizes Broyard's description in this article as laying the blame on the victim rather than the discriminating society. Interestingly, Broyard offers a description of the African American who denies his identity that applies to himself. In the Memoir, he does not offer any criticism of society as discriminatory. It is also remarkable that some of the topics Broyard chose to write on, like his "Portrait of the Inauthentic Negro" and "Portrait of the Hipster" deal with people who display the phenomenon of split consciousness. In Creole Renegades, Bénédicte Boisseron uses Homi Bhabha's concept to offer a vision of Creole identity as a hybrid.

${ }^{5}$ The issue here is not which figure comes first but the difference between metaphor and simile. Even from a cognitive perspective which sees that conceptual metaphors precede similes, the two figures are distinct.

Conceptual metaphors give form to a target domain by projecting structure from a source: in fact, some very abstract targets, like time and causation, may be structured almost entirely metaphorically. Similes, on the other hand, match structures construed as simultaneously present in both domains: similes do not add structure to a target, but highlight what's already there. (Israel 132)

In her compelling critique of reductive simile theories of metaphor, Lynne Tirrell confirms the difference. " $[T]$ here is a big difference between saying " $\mathrm{A}$ is a $\mathrm{B}$ " and saying that " $\mathrm{A}$ is like a B". The former entails A's inclusion in the set of B things, while the latter does not.... Since the semantic commitments of the two claims differ, the addition of the 'like' is not trivial" (341).

${ }^{6}$ In the "Postscript" to Kafka, Alexandra Broyard quotes her husband in a letter to the publisher: "In a way, I had been an expatriate in the Village, living in a style that was essentially foreign to me. I was flying, like a Freudian dream of flying, and the book 
ends with my attempt to come back down to earth" (148). Here again, he confirms that life in the Village was separate from the normal American life to which he belonged. Nevertheless, he does not acknowledge that he continued to live for the rest of his life under the guise of the character he invented in the Village.

${ }^{7}$ In Standby, Sandy Broyard, Anatole's wife, writes that in writing his memoir he was dealing with the "unresolved issues of his own childhood" and that writing was a "reinvention of himself" (205) confirming thereby the conclusion reached here.

\section{Works Cited}

Boisseron, Bénédicte. Creole Renegades: Rhetoric of Betrayal and Guilt in the

Caribbean Diaspora. Gainsville: University Press of Florida, 2014. Print.

Brainard, Marcus. Belief and Its Neutralization: Husserl's System of Phenomenology in Ideas I. New York: State University of New York Press, 2002. Print.

Broyard, Anatole. "Portrait of an Inauthentic Negro: How Prejudice Distorts the Victim's Personality." Commentary, 1 July 1950, pp. 56-64. Print.

-----. Intoxicated by my Illness. New York: Fawcett Columbine, 1993. Print.

-----. Kafka Was the Rage: A Greenwich Village Memoir. New York: Vintage Books, 1997. Print.

Broyard, Bliss. One Drop: My Father's Hidden Life - A Story of Race and Family Secrets. New York: Back Bay Books, 2008. Print.

Broyard, Sandy. Standby. New York: Knopf, 2005. Print.

Budick, Emily Miller. Blacks and Jews in Literary Conversation. Cambridge: Cambridge University Press, 1998. Print.

Carston, Robyn. Thoughts and Utterances: The Pragmatics of Explicit Communication. Oxford: Blackwell Publishing, 2002. Print.

Derrida, Jacques. Glas. Trans. John P. Leavey, Jr. and Richard Rand. Lincoln: University of Nebraska Press, 1986. Print.

Dostoevsky, Fyodor. Notes from the Underground. New York: Vintage Classics, 1994. Print.

Gates, Henry Louis. "The Passing of Anatole Broyard." Thirteen Ways of Looking at a Blackman. Ed. Henry Louis Gates. New York: Vintage Books, 1997. Print.

Israel, Michael, Jennifer Riddle Harding and Vera Tobin. "On Simile." Language, Mind and Culture. Ed. Michael Achard and Suzanne Kemmer. Stanford: CSLI publications, 2004. Print. 
Kaplan, Brett Ashley. “Anatole Broyard's Human Stain: Performing Postracial Consciousness." Philip Roth Studies, Volume 1, Number 2, Fall 2005, pp. 125-144. Print.

Ortega Y Gasset, José. The_Dehumanization of Art and Other Essays on Art, Culture and Literature. Princeton: Princeton University Press, 1968. Print.

Oshana, Mariana. The Importance of How We See Ourselves: Self-Identity and Responsible Agency. Maryland: Lexington Books, 2010. Print.

Tirrell, Lynne. "Reductive and Nonreductive Simile Theories of Metaphor." The Journal of Philosophy, vol. 88, no. 7, July 1991, pp. 337-358. Print. 